УДК 342. 951:(477)

\author{
Л. М. Руснак \\ кандидат юридичних наук, \\ доиент кафедри професійних та спеціальних правових дисииплін \\ ПВНЗ «Буковинський університет»
}

\title{
ПРАВОВА ПРИРОДА ПОНЯТТЯ «ОХОРОНА ЗДОРОВ’Я»
}

Постановка проблеми. Право на охорону здоров'я є невід'ємним правом людини. Це право кожного, що задеклароване як на міжнародному рівні, так і на національному. Важливість забезпечення цього права в Україні зростає з кожним днем. Це пов'язано з нестабільною та мінливою політикою держави у сфері охорони здоров'я, а також із соціальними та економічними чинниками, що мають першочергове значення для зміцнення, відновлення і підтримання стану здоров'я кожного, адже рівень забезпеченості фінансовими ресурсами безпосередньо впливає на якість та своєчасність надання особі медичної допомоги. Україна на сьогоднішній день перебуває у стані реформування системи охорони здоров'я, тому під час розробки законопроектів, програм або стратегій розвитку зазначеної сфери необхідно враховувати особливості економічного стану держави, демографічну ситуацію, наявність збройного конфлікту на Сході України, нерівність у фінансовій забезпеченості тощо.

Аналіз дослідження проблеми. Різні питання стосовно визначення поняття «охорона здоров'я», формування системи охорони здоров'я були предметом наукових досліджень багатьох авторів, таких як Ю.П. Битяк, В.В. Воробйов, Ю.В. Герус, Д.В. Карамишев, Н.І. Карпишин, О.М. Клименко, М.I. Мороз, В.Ф. Москаленко, В.М. Пономаренко, Л.М. Немець, М.Ю. Поворозник, Т.Г. Погребський, Т.Д. Сіташ, Т.М. Смірнова, О.Р. Ситенко, О.М. Шамич, C.I. Юрій, С.О. Ютовець, Н.П. Ярош та ін.

Як показує аналіз опрацьованої нами наукової літератури, необхідність дослідження правової природи поняття «охорона здоров’я» та історії формування системи, науковцями увага приділялась не достатньо. Тому метою статті $є$ проведення загальнотеоретичного аналізу на предмет визначення поняття «охорона здоров'я» та історії формування системи охорони здоров'я, що спрямовано на виконання законів шляхом розробки та встановлення підзаконних правил загального характеру.

Виклад основного матеріалу. Життя і здоров'я - найвищі первинні соціальні цінності, на основі яких формуються, визначаються й оцінюються всі інші орієнтири і блага сучасного суспільства, і які відображають біосоціальне буття людини. Визнання здоров'я як важливої гуманітарної цінності означає повагу до прав людини, а також рівність і соціальну справедливість. Здоров'я $€$ природним, невідчужуваним і невід'ємним благом, без якого тією чи іншою мірою втрачають значення інші цінності, оскільки нездорова людина так чи інакше обмежена у своїй фізіологічній і соціальній активності, у спілкуванні, у побуті, у виборі місця проживання, в освіті та трудовій діяльності тощо. Здоров'я є однією 3 найважливіших потреб і прагнень людини, однією з цілей розвитку суспільства, прогрес якого нерозривно пов'язаний з цим благом [13, с. 79].

Здоров'я $є$ важливим соціальним та економічним чинником, від рівня якого значно залежать економічні ресурси, фізичний, духовний i моральний потенціал суспільства. Велике значення здоров'я як вищого і природного блага обумовлює необхідність його охорони і захисту, у т.ч. і міжнародно-правового. Здоров'я людей є одним із найважливіших показників рівня соціально-економічного й екологічного благополуччя суспільства, його демографічного, духовно-культурного, політичного, наукового, біологічного й етичного потенціалу. Аналізоване благо є найбільш об'єктивним критерієм ефективності заходів на рівні законодавчого i виконавчих органів влади. Цей термін охоплює фізичні, психічні, духовні й соціальні аспекти життедіяльності [13, с. 79].

Історично у світі сформувалися різні моделі соціальної політики, зокрема модель політики у сфері охорони здоров'я, кожна з яких, поряд із загальними властивостями, відбиває національно-специфічні, соціально-економічні й політичні можливості держави [6, с. $131 ; 10$, с. 7].

У Конституції України (ст. 49) закріплено, що кожен має право на охорону здоров'я, медичну допомогу та медичне страхування. Охорона здоров'я забезпечується державним фінансуванням відповідних соціально-економічних, медико-санітарних і оздоровчо-профілактичних програм. Держава створює умови для ефективного і доступного для всіх громадян медичного обслуговування [2, с. 131]. Крім того, у ст. 50 Конституції України зазначено, що кожен має право на безпечне для життя і здоров'я довкілля та на відшкодування завданої порушенням цього права шкоди. Кожному гарантується право вільного доступу до інформації про стан довкілля, про якість харчових продуктів і предметів побуту, а також право на її поширення. Така інформація ніким не може бути засекречена $[14 ; 13$, с. 79$]$. 
Зміст права на охорону здоров' я і на медичну допомогу визначено ст. 283 і 284 Цивільного кодексу України (ЦК України). Ст. 285, 286, 287 і 290 ЦК України визначені також право на інформацію про стан свого здоров'я і на таємницю про нього [12, с. $20 ; 10$, с. 39].

Законодавче визначення поняття «здоров'я» можна розглядати як абсолютне здоров'я, яке дехто з дослідників, розглядає як ідеальне здоров'я, якого не існує в реальних умовах стану організму, а виступає як стандарт, до якого ми повинні прагнути [13, с. 90].

Деякі науковці пропонують таке визначення: «Здоров'я - це стан оптимального функціонування організму, доброго самопочуття людини, нормальної її життєдіяльності» [9].

O.M. Шамич пропонує таке визначення цього поняття: здоров'я - це максимально досяжний та оптимальний фізичний і психічний стан людського організму, який є необхідним для забезпечення біологічного існування, здатності до тривалого активного життя й відтворення здорового покоління [13, с. 90].

Міжнародна конференція з охорони здоров'я в Нью-Йорку в 1946 р. прийняла Статут Всесвітньої організації охорони здоров'я (далі - В003), у якому було сформульовано визначення здоров' я, яке після декількох десятиріч стало своєрідною відправною точкою у формуванні політики охорони здоров' я. «Здоров' я - це стан повного фізичного, духовного та соціального добробуту, а не тільки відсутність хвороб і фізичних дефектів» [15].

У Статуті головного міжнародного координаційного органу з охорони здоров'я зазначається, що володіння досяжним найвищим рівнем здоров'я $\epsilon$ одним із невід'ємних прав будь-якої людини незалежно від раси, релігії, політичних переконань, економічного та соціального становища. Уряди є відповідальними за здоров'я своїх народів, і ця відповідальність потребує проведення відповідних заходів соціального характеру [16, с. 168].

У визначенні ВООЗ в одну низку з традиційними критеріями здоров' я - фізичним (соматичним) і душевним (психічним) - поставлено також і спосіб життя, якого людина дотримується через соціальні й економічні обставини [6, с. 131]. Таким чином, складовою частиною державної політики $€$ турбота про здоров'я людей, тобто охорона здоров'я населення. Під охороною здоров'я слід розуміти складну систему державних, суспільних та індивідуальних заходів, які спрямовані на збереження здоров'я населення [9].

Законодавство України, зокрема ст. 3 «Основ законодавства України про охорону здоров'я», визначає охорону здоров'я як систему заходів, які здійснюються органами державної влади та органами місцевого самоврядування, їх посадовими особами, закладами охорони здоров'я, медичними та фармацевтичними працівниками і громадянами з метою збереження та відновлення фізіологічних і психологічних функцій, оптимальної працездатності та соціальної активності людини при максимальній біологічно можливій індивідуальній тривалості її життя [8]. Закріплення саме такого визначення враховує всі аспекти даного поняття та є логічним і завершеним, проте пропонуємо також проаналізувати визначення деяких науковців.

Так, Д.В. Карамишев трактує охорону здоров'я як систему заходів політичного, економічного, правового, соціального, культурного, наукового, медичного, санітарно-гігієнічного та протиепідемічного характеру, спрямованих на збереження та зміцнення здоров'я кожного громадянина, надання йому адекватної медичної допомоги у разі погіршення або втрати здоров'я [5, с. 236].

Охорона здоров'я розглядається багатьма вченими як суспільне благо, коли надання медичної допомоги кожній людині має важливе значення для суспільства загалом. У свою чергу, така позиція у більшості європейських країн стала частиною традиційного консенсусу щодо важливості дотримання принципу солідарності та всеохоплюючого доступу населення до ресурсів охорони здоров'я. 3 іншого боку, ринкові важелі за своєю природою засновані на припущенні, що кожна медична послуга $є$ товаром, який можна продати на відкритому ринку. Крім того, неокласична ринкова концепція потребує проведення чітких відмінностей між такими категоріями, як попит і пропозиція, тобто між покупцем і надавачем медичних послуг. Однак сучасна система охорони здоров'я передбачає чотиристоронні взаємовідносини (між пацієнтом, лікарем, медичним закладом і стороною, яка його фінансує) [6, с. $132 ; 17$, с. 245].

Аналіз загальнотеоретичної наукової літератури на предмет визначення поняття природного права людини у сукупності з іншими аспектами дослідження цього питання дає можливість запропонувати таке визначення права людини на охорону здоров'я як природного права: право на охорону здоров'я як загально-соціальне (природне) право людини - це можливість людини використовувати усі соціальні, насамперед державні, засоби, спрямовані на збереження, зміцнення, розвиток та, у випадку порушення, відновлення максимально досяжного рівня фізичного й психічного стану її організму [10, с. 90].

Орієнтиром останнього десятиріччя і на подальшу перспективу для вдосконалення охорони здоров'я в Європі і в кожній країні - члені Свропейського бюро ВООЗ визнано загальноєвропейську політику «Здоров'я для всіх». Вона передбачає, що всі країни повинні не тільки мати, але й здійснювати політику досягнення здоров'я для всіх людей на державному, регіональному та місцевому рівнях за підтримки відповідних структур. Основна мета 
політики «Здоров'я для всіх» полягає в забезпеченні справедливості в галузі охорони здоров'я та високої якості життя, а її головний орієнтир - усунення відмінностей у стані здоров'я, зумовлених соціальноекономічними чинниками [6, с. $132 ; 14$, с. $74 ;]$.

Висновки. Резюмуючи та проаналізувавши вище наведені визначення охорони здоров'я, вважаємо за доцільне дати власне: «охорона здоров'я система способів, засобів і методів, здійснюваних органами державної влади, органами місцевого самоврядування, а також кожною фізичною особою окремо, реалізація яких покликана зміцнювати (якщо це не є можливим, - зберігати на такому самому рівні), розвивати та відновлювати рівень фізичного й психічного стану організму людини.

\section{Jimepamypa}

1. Битяк Ю.П. Адміністративне право України : підручник. Київ : Юрінком Інтер, 2007. 544 с.

2. Дерега В.В. Соціальна і гуманітарна політика : навчальний посібник. Миколаїв : Вид-во ЧДУ ім. Петра Могили, 2012.178 с.

3. Історія охорони здоров'я України. Офіційний веб-портал Міністерства охорони здоров'я. URL: http:// www.moz.gov.ua/ua/portal/mtbr_healthserviceshistory.

4. Історія української культури : у 5 т. Т. 5. Кн. 3. Київ : Наук.думка, 2012.948 с.

5. Карамишев Д.В. Концепція інноваційних перетворень: міжгалузевий підхід до реформування системи охорони здоров'я (державно-управлінські аспекти) : монографія. Харків : Вид-во ХарРІ НАДУ «Магістр», 2004. $304 \mathrm{c}$.

6. Карамишев Д.В., Удовиченко Н.М. Основні принципи функціонування системи охорони здоров'я в контексті загальнолюдських цінностей соціальної держави. Медичне право України: правовий статус пацієнтів в Украйні та його законодавче забезпечення (генезис, розвиток, проблеми і перспективи вдосконалення) : матеріали II Всеукраїнської науково-практичної конференції 17-18 квітня 2008 р. Львів. C. 129-136. URL: http://medicallaw.org.ua/uploads/ media/02_129_01.pdf.

7. Мартиненко О.В. Система охорони здоров'я України в період 1917-2007 pp. Керівники, подіï, факти, коментарі. Новини медицини та фармації. 2007. № 9 (213). URL: http://www.mif-ua.com/archive/ article/1537.

8. Основи законодавства України про охорону здоров'я : Закон України від 19. листопада 1992 р. № 2801ХII. Відомості Верховної Ради України. 1993. № 4.

9. Права людини у сфері охорони здоров'я : практичний посібник. URL: http://medicallaw.org.ua/ vydavnytstvo/praktychnyi-posibnyk-prava-liudynyu-sferi-okhorony-zdorovia/5-zagalna-kharakteristikapravovoji-sistemi-i-sistemi-okhoroni-zdorovjaukrajini/54-sistema-okhoroni-zdorovja-zagalnii-ogljad/.

10. Сенюта I.Я. Право людини на охорону здоров’я та його законодавче забезпечення в Україні (загальнотеоретичне дослідження) : дис. ... канд. юрид. наук : 12.00.01 / Львівський національний університет ім. І. Франка. Львів, 2006. 102 с.

11. Ступак Ф.Я. Розвиток охорони здоров'я в Україні у другій половині ХХ століття. Історія: Гра Hi. 2015. № 2 (118). C. 158-162.

12. Українська радянська енциклопедія. Т. 8. Київ : УРЕ, $1982.576 \mathrm{c}$.
13. Шамич О.М. Поняття та структура природного права людини на охорону здоров'я. Актуальні проблеми навчання та виховання людей з особливими потребами. 2014. № 11. С. 75-92.

14. Конституція України : Закон України від 28 червня 1996 р. № 254к /96-ВР. Відомості Верховної Ради України. 1996. № 30.

15. Статут (Конституція) Всесвітньої організації охорони здоров'я: Міжнародний документ від 22 липня 1946 р. Офіиійний веб-портал Верховної Ради України. URL: http://zakon2.rada.gov.ua/laws/show/995_599.

16. Основные документы Всемирной органйзации здравоохранения. Женева, 2003. 261 с.

17. Салтман Р., Фигейрас Дж. Реформы системы здравоохранения в Европе: анализ современных стратегий. Москва : Геотар Медицина, 2000. $423 \mathrm{c.}$

18. Романенко А.Е. Здравоохранение и медицинская наука в Украинской ССР. Київ, 1987. Т. 1. 479 с.

\section{Анотація}

Руснак Л. М. Правова природа поняття «охорона здоров'я». - Стаття.

Стаття присвячена дослідженню поняття «охорона здоров'я» та історії формування системи охорони здоров'я в Україні. Однією з проблем, яка постає в контексті цього завдання, $є$ проведення загальнотеоретичного аналізу наукової літератури на предмет визначення поняття природного права людини на охорону здоров'я, а також процесу становлення і розвитку системи охорони здоров'я в їі історичному аспекті, що сьогодні потребує на законодавчому рівні відповідного вдосконалення та розширення. 3'ясовано, що охорона здоров'я повинна розглядатися як суспільне благо, коли надання медичної допомоги кожній людині має важливе значення для суспільства загалом. У свою чергу, така позиція в більшості європейських країн стала частиною традиційного консенсусу відносно важливості дотримання принципу солідарності та всеохоплюючого доступу населення до ресурсів охорони здоров'я. 3 іншого боку, ринкові важелі за своєю природою засновані на припущенні, що кожна медична послуга є товаром, який можна продати на відкритому ринку. Наголошено, що законодавче визначення поняття «здоров'я» можна розглядати як абсолютне здоров'я, яке дехто з дослідників, розглядає як ідеальне здоров'я, якого не існує в реальних умовах стану організму, а виступає як стандарт, до якого ми повинні прагнути. Визначено, що здоров'я є важливим соціальним та економічним чинником, від рівня якого значно залежать економічні ресурси, фізичний, духовний і моральний потенціал суспільства. Велике значення здоров'я як вищого і природного блага зумовлює необхідність його охорони і захисту, у т.ч. і міжнародно-правового. Зроблено висновок, що охорона здоров'я - система способів, засобів і методів, здійснюваних органами державної влади, органами місцевого самоврядування, а також кожною фізичною особою окремо, реалізація яких покликана зміцнювати (якщо це не є можливим, - зберігати на такому ж рівні), розвивати та відновлювати рівень фізичного і психічного стану організму людини.

Ключові слова: поняття «охорона здоров'я», історія формування системи охорони здоров'я, медична допомога та медичне страхування, основи законодавства про охорону здоров'я, державна політика.

\section{Summary}

Rusnak L. M. The legal nature of the concept of «healthcare». - Article.

The article is devoted to the study of the concept of «healthcare» and the history of the formation of the 
healthcare system in Ukraine. One of the problems that arises in the context of this assignment is to conduct a general theoretical analysis of the scientific literature with a view to defining the concept of a person's natural right to health protection, as well as the process of formation and development of the healthcare system in its historical aspect. What today requires at the legislative level the corresponding improvement and expansion. It has been found that healthcare should be considered as a public good, when providing medical care to every person is important for society as a whole. In turn, this position in most European countries has become part of the traditional consensus on the importance of adhering to the principle of solidarity and universal access of the population to health resources. On the other hand, market forces are inherently based on the assumption that each medical service is a commodity that can be sold on the open market. It is stressed that the legislative definition of the concept of «health» can be con- sidered as an absolute health, which some researchers consider as an ideal health, which does not exist in the real state of the organism, and acts as a standard to which we must strive. It is determined that health is an important social and economic factor, which depends on the level of which economic resources, physical, spiritual and moral potential of society depend heavily. The importance of health as a higher and natural good causes the need for its protection and protection, including international legal. It is concluded that healthcare is a system of methods, means and methods implemented by state authorities, local self-government bodies, as well as by each individual, the implementation of which is intended to strengthen (if this is not possible, to maintain at the same level), to develop and restore the level of physical and mental state of the human body.

Key words: concept of "health protection», history of the formation of the health care system, medical care and medical insurance, basics of healthcare legislation, state policy. 